\title{
Phosphorous recovery from sewage sludge ash suspended in water in a two- compartment electrodialytic cell
}

\author{
Ottosen, Lisbeth M.; Jensen, Pernille Erland; Kirkelund, Gunvor Marie
}

Published in:

Waste Management

Link to article, DOI:

10.1016/j.wasman.2016.02.015

Publication date:

2016

Document Version

Peer reviewed version

Link back to DTU Orbit

Citation (APA):

Ottosen, L. M., Jensen, P. E., \& Kirkelund, G. M. (2016). Phosphorous recovery from sewage sludge ash suspended in water in a two-compartment electrodialytic cell. Waste Management, 51, 142-148.

https://doi.org/10.1016/j.wasman.2016.02.015

\section{General rights}

Copyright and moral rights for the publications made accessible in the public portal are retained by the authors and/or other copyright owners and it is a condition of accessing publications that users recognise and abide by the legal requirements associated with these rights.

- Users may download and print one copy of any publication from the public portal for the purpose of private study or research.

- You may not further distribute the material or use it for any profit-making activity or commercial gain

- You may freely distribute the URL identifying the publication in the public portal 


\title{
1 Phosphorous recovery from sewage sludge ash suspended
}

\section{in water in a two-compartment electrodialytic cell}

\author{
Lisbeth M. Ottosen*, Pernille E. Jensen, Gunvor M. Kirkelund
}

\begin{abstract}
Department of Civil Engineering, Brovej, Building 118, Technical University of Denmark, 2800 Kgs. Lyngby, Denmark.*LO@byg.dtu.dk
\end{abstract}

\section{ABSTRACT}

Phosphorus (P) is indispensable for all forms of life on Earth and as $\mathrm{P}$ is a finite resource, it is highly important to increase recovery of $\mathrm{P}$ from secondary resources. This investigation is focused on $\mathrm{P}$ recovery from sewage sludge ash (SSA) by a two-compartment electrodialytic separation (EDS) technique. Two SSA are included in the investigation and they contained slightly less $\mathrm{P}$ than phosphate rock used in commercial fertilizer production and more heavy metals. The two-compartment electrodialytic technique enabled simultaneous recovery of P and separation of heavy metals. During EDS the SSA was suspended in water in the anolyte, which was separated from the catholyte by a cation exchange membrane. Electrolysis at the anode acidified the SSA suspension, and hereby P, Cu, Pb, Cd and Zn were extracted. The heavy metal ions electromigrated into the catolyte and were thus separated from the filtrate with P. 
21 More than 95\% P was extracted from both SSAs. The charge transfer to obtain this varied when treating

22 the two SSAs, and for one ash it was about 30\% higher than for the other as result of a higher buffering capacity against acidification. The repeatability of EDS results between experiments with the same SSA and the same experimental conditions was good, which shows that the process is easy to control at the studied laboratory conditions. About $80 \% \mathrm{P}$ and $10 \%$ of the heavy metals remained in the filtrate from the anolyte after treatment of both SSAs. The heavy metal content relative to $\mathrm{P}$ in the filtrate by far meet the limiting values for use of industrial wastes as fertilizers, thus the filtrate is ready for direct processing into P-fertilizer.

\section{INTRODUCTION}

By the human perspective, resources are non-renewable when their rate of consumption exceeds the rate of recovery. Depletion of $\mathrm{P}$ from primary sources is a result of non-sustainable use. It is time to acknowledge the reality of the finite limit and develop methods for recovery of P from secondary sources. One such source is ash from incineration of sewage sludge (SSA). Sewage sludge incineration is a well proven technology with hundreds of plants worldwide (Werther and Ogada, 1999); 1.7 million tonnes of SSA are produced annually world-wide, and the production is likely to increase in the future (Donatello \& Cheeseman 2013). The concentration of $\mathrm{P}$ in SSA is generally 5-10\% (Cyr et al. 2007), thus approaching the content in virgin phosphorite, which indicates that SSA is a significant potential secondary P resource. There is limited gain in crop yield if SSA is spread directly at agricultural land as $\mathrm{P}$ is not in a plant available form in the ash. In addition, heavy metals are concentrated in the SSA during incineration, which prohibits use of SSA in agriculture. 
Different techniques are under development for recovery of P from SSA. The techniques can be grouped

44

in two: thermochemical treatment or chemical extraction. These methods are reviewed in (Donatello \& Cheeseman 2013). Current practice for handling the SSA from the two Danish plants, from where ash was sampled for the present investigation, is landfilled in special landfills with only SSA. The purpose is to recover the P from the landfilled ashes, when proper and economical methods have been developed. This work updates the technology where the $\mathrm{P}$ is extracted in acid. A major problem with acid extraction is the simultaneous extraction of heavy metals and P (Donatello et al. 2010a; Ottosen et al. 2013). In order to obtain a clean $\mathrm{P}$ product, various processes for separation of $\mathrm{P}$ and heavy metals have been suggested: pH adjustment (Franz 2008, Takahashi 2001), sulfide precipitation (Franz, 2008), cation exchange (Franz, 2008; Donatello et al. 2010b) and electrodialytic separation (Ottosen et al. 2014, Guedes et al. 2014, Ebbers et al. 2014a). The first three separation techniques require a two-step treatment, first P extraction and subsequent separation. In electrodialytic separation the P extraction and heavy metal separation occur simultaneously. The present paper focus on electrodialytic separation and reports laboratory tests with two-compartment electrodialytic P recovery from sewage sludge ash from incineration of municipal wastewater sludge. A major focus is on describing the major elements and heavy metal content of the recovered $\mathrm{P}$ and comparing it to commercial P-fertilizers. The ashes originate from the two (out of three) largest sewage sludge incineration plants in Denmark as it is interesting to investigate the robustness of EDS method for ashes from both plants.

\subsection{Two-compartment EDS}

The principle of the two-compartment EDS setup used in this paper is illustrated in figure 1. The major objective with this setup is a simultaneous extraction of $\mathrm{P}$ and removal of heavy metals from the liquid with P. When the electrical DC current is applied to the electrodes, the SSA suspension will gradually be 
acidified due to electrolysis at the anode $\left(\mathrm{H}_{2} \mathrm{O} \rightarrow 2 \mathrm{H}^{+}+1 / 2 \mathrm{O}_{2}(\mathrm{~g})+2 \mathrm{e}^{-}\right)$. During the acidification heavy metals and P are extracted from the ash. The heavy metals are transported by electromigration over the cation exchange membrane (CEM) and concentrate in the cathode compartment. The extracted $\mathrm{P}$ remains in the filtrate of the ash suspension. Hereby simultaneous extraction and separation is obtained.

A two-compartment electrodialytic setup has previously been tested for purification of wet industrial phosphoric acid (Touaibia et al. 1996), but this setup was opposite to the one of this paper. In (Touaibia et al. 1996) the two compartments were separated by an anion exchange membrane (AEM) and the phosphoric acid to be treated was placed in the cathode compartment. Here the impurities were retained in the catholyte and P electromigrated to the anolyte where phosphoric acid was formed with protons produced by the anodic electrolysis. The concentration of the phosphoric acid produced by this method was, however, limited by proton leakage through the AEM (Touaibia et al. 1996). The two compartment system with the cathode placed in reject water from a WWWT plant and separation of P into the anolyte was tested in (Ebbers et al. 2015b), however, the increase in $\mathrm{pH}$ caused $\mathrm{P}$ precipitation and limited the recovery. A three compartment EDS system based on the idea of recovering phosphoric acid in the anolyte and heavy metals in the catholyte was tested by Ottosen et al. (2014) and by Guedes et al (2014). These works, however, showed that the transport of P into the anolyte was inefficient. Phosphorous has four speciation steps: $\mathrm{H}_{3} \mathrm{PO}_{4}, \mathrm{H}_{2} \mathrm{PO}_{4}^{-}, \mathrm{HPO}_{4}{ }^{2-}$ and $\mathrm{PO}_{4}{ }^{3-}$ and the corresponding acid constants (pKa, 298 $\mathrm{K})$ are 2.12; 7.2 and 12. Thus at $\mathrm{pH}$ less than 2, $\mathrm{P}$ is present as phosphoric acid without any charge and thus not mobile for electromigration. But at the same time $\mathrm{pH}$ needs to be less than 2 to fully extract $\mathrm{P}$ from SSA (Ottosen et al. 2013). Contrarily, the heavy metal transport into the catholyte progressed well in the three compartment electrodialytic cell, as heavy metals are present in ionic form as released from the SSA by acid (Ottosen et al 2014). The insufficient P recovery in the anode compartment using the 
three compartment EDS cell formed basis for the idea of a simpler setup; the two compartment EDS cell. The overall idea of the two-compartment EDS is to keep the $\mathrm{P}$ in the filtrate to which it is extracted and transport the heavy metals out from this filtrate in the applied electric field. By placing the anode directly in the suspension a faster acidification and subsequent release of $\mathrm{P}$ and heavy metals is obtained compared to the three compartment cell.

Phosphorous extraction in two-compartment EDS was experimentally compared to three-compartment EDS (Ebbers et al. 2014a) where experiments were made with ash suspended in distilled water or $\mathrm{H}_{2} \mathrm{SO}_{4}$. The fastest recovery of $\mathrm{P}$ was obtained in the two-compartment cell when the SSA was suspended in $\mathrm{H}_{2} \mathrm{SO}_{4}$. However, when suspending the ash in $\mathrm{H}_{2} \mathrm{SO}_{4}$ gypsum was formed by $\mathrm{Ca}^{2+}$ released from the ash and the $\mathrm{SO}_{4}{ }^{2-}$ from the acid (Ottosen et al. 2014). The formation of gypsum increases the volume of particulate matter to be landfilled. Environmentally as well as economically it would be beneficial to use the remaining ash in e.g. construction materials rather than landfilling. SSA has been suggested to be used in different construction materials. Donatello \& Chesemann (2013) reviewed the use in: sintered ceramics (bricks and lightweight aggregates) and in concrete as cement replacement or in the production of the cement. The gypsum formation may hamper such use. Also other anions, such as $\mathrm{Cl}^{-}$or $\mathrm{NO}_{3}{ }^{-}$added by use of other mineral acids for $\mathrm{P}$ dissolution may impede the use of the residual ash in construction materials and they will be impurities in the phosphoric acid. This problem is completely avoided by the use of EDS and acidification thorough electrolysis at the anode. For use in concrete, milling of SSA showed very beneficial due to improved pozzolanic activity (Donatello et al. 2010a). For this reason and because the finer particle size after milling eased keeping the ash suspended during EDS, the SSA was milled prior to treatment in the present work. Experiments were conducted with SSA's from two different incineration plants. We investigated and compared the recovery of $\mathrm{P}$ from the two SSAs and the 
112 separation of heavy metals from the filtrate into the catholyte. Finally the purity of a phosphorous salt

113 produced from evaporation the water from the filtrate was evaluated.

\section{MATERIALS AND METHODS}

\subsection{Experimental ashes}

117 SSAs from the two major Danish mono-incineration plants were used. The sludge incinerated at both 118 plants originated from municipal wastewater treatment. Iron was used in both waste water facilities to 119 precipitate $\mathrm{P}$, and the sewage sludge was incinerated in a fluidized bed combustor at about $850^{\circ} \mathrm{C}$. Ash 120 A was sampled at Spildevandscenter Avedøre and ash B was from Lynettefællesskabet. Both ashes were 121 sampled directly from ash silos when the ash was filled in trucks for transportation away from the plants. 122 Ash A was sampled as a mix of electrofilter ash and bag filter ash (2\%), whereas ash B was sampled 123 directly after the electrofilter. After sampling, the ashes were stored in closed plastic containers at room 124 temperature. Before use, the ashes were milled for 30 seconds in a Vibrating Cup Mill PULVERISETTE 1259.

\subsection{Analytical and ash characterization}

Characterization was made with dried ash $\left(105^{\circ} \mathrm{C}, 24\right.$ hours). Concentrations of $\mathrm{P}, \mathrm{Cu}, \mathrm{Pb}, \mathrm{Zn}$ and $\mathrm{Cd}$ were measured in all samples with a Varian 720-ES ICP-OES (Inductively Coupled Plasma - Optical Emission Spectrometry). SSA samples were pre-treated in accordance to Danish Standard DS259: $1.0 \mathrm{~g}$ ash and $20.0 \mathrm{ml}(1: 1) \mathrm{HNO}_{3}$ was heated at $200 \mathrm{kPa}\left(120^{\circ} \mathrm{C}\right)$ for 30 minutes and filtered through a 0.45 $\mu \mathrm{m}$ filter prior to the analysis by ICP-OES. Ash $\mathrm{pH}$ and conductivity were measured after suspending 
134 the suspension with Radiometer electrodes. Water content was measured as weight loss after 24 hours at $135105^{\circ} \mathrm{C}$ (calculated as weight loss over the weight of the wet sample). Loss on ignition (LoI) was found 136 after 30 minutes at $550^{\circ} \mathrm{C}$. Five duplicates of each of these analyses were made. Solubility in water was evaluated: $50.0 \mathrm{~g}$ ash suspended in $500 \mathrm{ml}$ distilled water and agitated for $1 \mathrm{~min}$. After settling the water was decanted. New $500 \mathrm{ml}$ distilled water added. This was repeated so the ash was washed three times.

139 Finally the suspension was filtered and the ash dried and weighed.

\subsection{Experiments with two-compartment electrodialytic P recovery}

142 The experiments were conducted in a cylindrical cell as shown in figure 1 . The length of the anode compartment with ash suspension was $10 \mathrm{~cm}$ and the length of the cathode compartment $5 \mathrm{~cm}$. The internal diameter of both compartments was $8 \mathrm{~cm}$. The cation exchange membrane was from Ionics (CR67 HUY N12116B). The electrodes were made of platinum coated titanium wire (diameter $3 \mathrm{~mm}$ ) obtained from Permascand $(\circledR)$ and the length of the electrode in the catolyte was approximately $4 \mathrm{~cm}$. A 147 power supply (Hewlett Packard E3612A) was used to maintain a constant current of $50 \mathrm{~mA}$. The SSA was kept suspended in the anode compartment by an overhead stirrer (RW11 basic from IKA). In the cathode compartment $500 \mathrm{~mL} 0.01 \mathrm{M} \mathrm{NaNO}_{3}$ adjusted to $\mathrm{pH} 2$ with $\mathrm{HNO}_{3}$ was circulated. The circulation of the catolyte ensures a continuous flow in this compartment and prevents build-up of high concentration gradients at the surface of the cation exchange membrane and it flushes the produced $\mathrm{H}_{2}$ gas from electrolysis out of the compartment. During experiments, $\mathrm{pH}$ was adjusted manually in the cathode compartment to between 1 and 2 daily with $1 \mathrm{M} \mathrm{HNO}_{3}$. Conductivity and $\mathrm{pH}$ in the ash suspension and voltage between electrodes were also measured daily. 
156 Totally 12 EDS experiments were made with duration and type of SSA as the two varying parameters

157 (see table 1). In every experiment $25 \mathrm{~g}$ SSA was suspended in $350 \mathrm{ml}$ distilled water (corresponding to 158 a liquid to solid ratio L:S = 14). Three identical experiments A4-A6 were conducted to investigate the 159 repeatability of the results.

160

161 At the end of the EDS experiments the suspension was filtered at atmospheric pressure. Contents of $\mathrm{P}$, $162 \mathrm{Cu}, \mathrm{Zn}, \mathrm{Pb}$ and $\mathrm{Cd}$ were measured in the ash, solutions, cation exchange membrane and on the cathode.

163 The ash was dried before measurement of the same chemical elements (triplicate measurements). The 164 contents in the cation exchange membrane were measured after extraction in $1.0 \mathrm{M} \mathrm{HNO}_{3}$ and rinsing of the electrodes prior to measurement was done in 5.0 $\mathrm{M} \mathrm{HNO}_{3}$. For further investigating the purity of the $\mathrm{P}$ produced, the filtrate from experiment $\mathrm{A} 6$ was placed in an oven at $50^{\circ} \mathrm{C}$ in order to evaporate the water and produce a salt. As shown later the P extraction had reached maximum in experiment A6 and this was the reason for choosing it. The purpose was twofold: to analyze the concentration of heavy 169 metals in relation to $\mathrm{P}$ and to evaluate the quality of the produced salt as basis for $\mathrm{P}$ fertilizer. The produced salt was stored in a desiccator to hinder hygroscopic uptake of moisture from the air. The salt was characterized by the total content of macro elements (P, Ca, Fe and $\mathrm{Al})$, heavy metals $(\mathrm{Cu}, \mathrm{Pb}, \mathrm{Zn}$ and Cd) after DS259 (described above). It was checked that the macro elements analyzed were those present in the salt by elemental mapping of the salt crystals using Scanning Electron Microscopy with Energy Dispersive X-Ray Analysis (SEM-EDX). The water soluble fraction in the salt of the same elements extracted in distilled water at liquid to solid ratio (L:S) 2.5 was measured as well.

\section{RESULTS AND DISCUSSION}

\subsection{The SSAs as secondary $P$ resource}


178 Characteristics of the SSAs are shown in table 2. Both ashes were alkaline, but Ash A had lower $\mathrm{pH}(\mathrm{pH}$ 179 9.5) than Ash B ( $\mathrm{pH}$ 12.4). Ash B contained a larger water soluble fraction than ash A, seen from both 180 the higher water soluble fraction and the higher conductivity when suspended in water.

It is interesting to compare the SSAs as being secondary resources for $\mathrm{P}$ to the primary resource being the phosphate rock. Phosphorus pentoxide $\left(\mathrm{P}_{2} \mathrm{O}_{5}\right)$ is the commonly reported constituent of the phosphate rock. The economic grade of phosphate rock varies from $25 \%$ to $37 \% \mathrm{P}_{2} \mathrm{O}_{5}$ (Gupta et al 2014). This concentration range corresponds to $110-160 \mathrm{~g}$ P/kg phosphate rock and thus the $\mathrm{P}$ concentration in SSAA $(110 \mathrm{~g} / \mathrm{kg})$ is exactly at the lower end of this range, but the concentration in SSA-B (73 g/kg) is lower. The concentrations in the SSAs are though high enough to be considered as secondary P resources. Ores of the phosphorous rock contain various toxic metals and radionuclides which later are transferred to phosphate fertilizers (Gupta et al. 2014). The concentrations $\mathrm{Cu}, \mathrm{Zn}$ and $\mathrm{Pb}$ in different phosphate rock for production of fertilizer were compiled by (Aydin et al 2010), and the ranges reported were 6-130 mg $\mathrm{Cu} / \mathrm{kg}$, 6-515 mg Zn/kg and 4-455, 93-2060 mg Pb/kg, 0.1 - $60 \mathrm{mg} \mathrm{Cd/kg.} \mathrm{The} \mathrm{heavy} \mathrm{metal}$ concentrations reported in literature in different SSAs were collected in (Cyr et al 2007): 200-5400 mg $\mathrm{Cu} / \mathrm{kg} ; 1080-10,000 \mathrm{mg} \mathrm{Zn/kg}, 93-2060 \mathrm{mg} \mathrm{Pb} / \mathrm{kg}$ and 4-94 mg Cd/kg. In general Zn and $\mathrm{Cu}$ concentrations in SSAs are thus higher than in phosphate rock, $\mathrm{Pb}$ concentrations are overlapping in the high range of phosphate rocks and low range of SSA. The concentration ranges are overlapping in the case of $\mathrm{Cd}$, though higher $\mathrm{Cd}$ concentrations were found in the SSAs. The ashes of the present investigation follow this general trend, yet the heavy metal concentration is low. The concentrations in the two SSAs of the present investigation fall within the lower ends of these ranges for heavy metals in SSA except for Pb in SSA-B and Cd in both ashes, which are even lower than the lowest concentration previously reported. In summary, the SSAs contained slightly less $\mathrm{P}$ than phosphate rock used in 
commercial fertilizer production and more heavy metals. The heavy metals in P fertilizer are taken up by the crops (Gupta et al. 2014) and if the P related heavy metal concentration in SSA is not reduced, this issue causes concern in the use of SSA as resource for $\mathrm{P}$ fertilizer. Thus separation of $\mathrm{P}$ and heavy metals from SSA is important.

\subsection{EDS process repeatability}

Acceptable mass balances (defined as mass of an element in the different parts at the end of the experiment over the mass of the element initially in the ash) were obtained for $\mathrm{P}, \mathrm{Cu}, \mathrm{Zn}$ and $\mathrm{Pb}$ in every experiment (90-110\%), whereas for Cd, the mass balances were not this good due to a low initial concentration. Subsequently only the distributions for $\mathrm{Cu}, \mathrm{Zn}$ and $\mathrm{Pb}$ from the EDS experiments are given. The content of $\mathrm{Cd}$ in the final P product is discussed on basis of the produced salt later.

The repeatability of EDS experiments can be evaluated by comparing the three identical experiments with SSA-A and the duration 10 days (A4 to A6). In each of these three experiments about $54 \%$ ash was dissolved during the treatment and final $\mathrm{pH}$ of the suspension was 1.1 (table 1). The distribution of $\mathrm{P}$, $\mathrm{Cu}, \mathrm{Pb}$ and $\mathrm{Zn}$ in ash, filtrate and cathode compartment (cation exchange membrane, catolyte and at the cathode) are shown in figure 2. The average values are given with error bars showing minimum and maximum values. The separation results were very similar for the three experiments and the deviation from the average value was $5 \%$ or less. Almost all P was extracted, and only 2-3\% remained in the ash at the end of the experiments. Around $80 \% \mathrm{P}$ was found in the filtrate of the suspension. Also for each of the heavy metals the distributions are the same. For $\mathrm{Cu}$ and $\mathrm{Zn}$ the major parts are found in the cathode compartment $(>70 \%)$ whereas $60 \% \mathrm{~Pb}$ remained in the ash. On the basis of the very similar result 
223 obtained in these experiments A4-A6 it was decided to make the remaining experiments of the 224 investigation as single experiments.

225

226

\subsection{Optimal duration of EDS for $P$ recovery}

227 The development in distribution of $\mathrm{P}, \mathrm{Zn}, \mathrm{Pb}$ and $\mathrm{Cu}$ as result of the EDS duration is seen in figure 3 228 (SSA-A) and figure 4 (SSA-B). The general trend between the two ashes is a slower extraction of all four 229 elements from SSA-B. During the first 5 days less than $10 \%$ of each element was released from SSA-B, 230 whereas about $80 \% \mathrm{P}$; 65\% $\mathrm{Zn}$ and $\mathrm{Cu}$; and 10\% Pb were released from SSA-A. This corresponds to the 231 faster acidification of the suspension with SSA-A and faster ash dissolution (table 1). This is in accordance with previous findings, as release of both $\mathrm{P}$ and heavy metals from SSA was shown to increase with decreasing pH (Ottosen et al. 2013, Donatello et al. 2010). It was also previously shown that different SSAs have different buffering capacities and require different amounts of acid for $\mathrm{P}$ extraction (Ottosen et al. 2013) and this was also the case for the two present ashes even if they are both from fluidized bed incineration of Fe rich ash at about $850^{\circ} \mathrm{C}$.

Almost all P (>95\%) was extracted between 5-7 days of EDS of SSA-A and between 7-10 days of SSA$\mathrm{B}$ (figures 3 and 4). The $\mathrm{P}$ extraction corresponds to the time where $\mathrm{pH}$ reaches below 2 (table 1), which again corresponds to the finding for SSA-A, reported in (Ottosen et al. 2013) for chemical extraction in $\mathrm{HNO}_{3}$ where $50-60 \% \mathrm{P}$ was extracted at $\mathrm{pH} 2$ and 85-100\% $\mathrm{P}$ at $\mathrm{pH}$ of about 1 from this ash. Results with two-compartment EDS was reported in (Ebbers et al 2015a) with SSA from the same plant as SSAA of the present investigation but with lower L:S (10 vs. 14) and the same current. The lower L:S prolonged the extraction time slightly as the buffering capacity of the suspension increases with ash amount. In (Ebbers et al 2015a) about 80\% P was extracted during 7 days. 
246 For both SSAs prolonging EDS after the time where full P extraction was obtained meant a loss of P into

247 the cathode compartment (figures 3(d) and 4(d)). After 14 days of EDS the lost P was approximately $24818 \%$ for both ashes. When terminating the experiments at the point where maximum $\mathrm{P}$ extraction is 249 obtained the loss of $\mathrm{P}$ into the cathode compartment is about $10 \%$ from both ashes and this loss seem 250 hard to hinder. As the two compartments are separated by a CEM, which hinder transport of anions, the 251 P transported into the catholyte may have been transported as neutrally charged complexes by diffusion 252 due to the concentration difference in the two compartments or by electromigration as cationic species 253 may be formed e.g. from the reactions: $\mathrm{Al}^{3+}+\mathrm{H}_{2} \mathrm{PO}_{4}{ }^{-} \rightarrow \mathrm{AlH}_{2} \mathrm{PO}_{4}{ }^{2+}$ or $\mathrm{Al}^{3+}+\mathrm{H}_{2} \mathrm{PO}_{4}{ }^{2-} \rightarrow \mathrm{AlH}_{2} \mathrm{PO}_{4}{ }^{+}$ 254 (Nordstrom \& May, 1989). During the two experiments with duration of 14 days A7 and B4, 45\% and 255 $32 \% \mathrm{Al}$ was transported into the cathode compartment, respectively, and it is possible that some of the 256 Al had formed positively charged complexes with P. Incineration of sewage sludge is used worldwide, but an emerging technology is low-temperature gasification, which allows energy production from biomass resources like sewage sludge with high contents of low melting point ash compounds, which can cause boiler operational problems in the more traditional incineration (Skoglund et al. 2013). Viader et al. (2015) tested two compartment EDS (at L:S 10 and an applied current of $50 \mathrm{~mA}$ ) from ash from gasification of two different municipal sewage sludges from a plant where $\mathrm{P}$ was captured $50 \%$ biologically and 50\% chemically (with Fe and Al chlorides) and a plant where P was mainly removed biologically with a minor amount of Fe salts (this latter was co-gasified with wheat straw pellets). During 7 days 26\% and 90\% P was recovered by EDS, respectively. The low P-extraction from the first ash was suggested being due to low-soluble Fephosphates formed during the gasification. This hypothesis is supported by the good EDS result from the other ash, with only a minor content of Fe. Even though the SSA from the present investigation originates from sludge where Fe-salts were used for $\mathrm{P}$ precipitation, the EDS extraction of $\mathrm{P}$ is not hampered by 
269 this, probably because iron oxides are formed during incineration rather than iron phosphates, so the

270 choice of thermal process influences $\mathrm{P}$ extractability from the ash. The possible EDS for extraction of $\mathrm{P}$ 271 and separation of heavy metals from SSA was shown being dependent on the precipitation chemicals 272 used at the WWWT in (Ottosen et al 2014), so this is the case for both gasification and incineration ashes.

273

$274 \quad 3.4$ Heavy metal removal

275 As well as P, the heavy metals were mobilized faster from SSA-A than SSA-B (figures 3 and 4). The 276 mobilization of $\mathrm{Cu}$ and $\mathrm{Zn}$ was faster than $\mathrm{Pb}$ from both ashes, i.e. $\mathrm{Zn}$ and $\mathrm{Cu}$ were mobilized at a higher $277 \mathrm{pH}$. The nature and proportion of minerals controlling the mobilization behavior of the different heavy 278 metals from sewage sludge ash have not yet been studied in-depth. The mineralogy in SSA represents an 279 assemblage of crystalline and amorphous phases and it is a very complex system. However, the finding 280 that $\mathrm{Pb}$ is mobilized to a lesser extent than $\mathrm{Cu}$ and $\mathrm{Zn}$ is in accordance to findings from chemical 281 extraction in acid for SSAs (Ottosen et al. 2013), three compartment EDS (Ottosen et al 2014, Guedes et 282 al. 2014), two-compartment EDS (Ebbers et al 2015a) and it is also a general finding using three283 compartment EDS for treatment of different ash types e.g. municipal solid waste incinerator fly ash 284 (Pedersen et al 2003) and wood ash (Ottosen et al 2007).

285

286 At day 10 the $\mathrm{pH}$ in both ash suspensions reached approximately 1 (table 2). At this point the mobilized 287 percentages were:

288 SSA-A: $88 \% \mathrm{Cu}, 42 \% \mathrm{~Pb}$ and $80 \% \mathrm{Zn}$

289 SSA-B: $41 \% \mathrm{Cu}, 39 \% \mathrm{~Pb}$ and $29 \% \mathrm{Zn}$

290 After this point $\mathrm{pH}$ stabilized in both experimental series and the mobilization of the heavy metals 291 stopped. 
293 Jensen et al. (2006) reported remediation results for $\mathrm{Pb}$ from soil fines in a three-compartment

294 electrodialytic cell. The distribution of $\mathrm{Pb}$ in the cell over time was reported in a similar way as figures 2953 and 4 in the present work. The work by Jensen et al. (2006) clearly illustrated how the removal of Pb 296 underwent four phases:

(1) a “lag-phase”, where removal was substantially absent

(2) a high removal rate involving dissolution of $\mathrm{Pb}$ into the soil solution

(3) low removal rate, where the already dissolved $\mathrm{Pb}$ was removed from solution

(4) no further Pb-removal was obtained as the treatment proceeded.

The same four phases can be used to describe the removal of the heavy metals from the SSAs in the present investigation. The "lag-phase" (1) is the phase until the buffering capacity of the ash is exceeded and the suspension reaches an acidification level, where the heavy metal is released (2). The duration of this phase was dependent on both the buffering capacity of the SSA and the actual heavy metal. The treatment should be finished by the end of phase (3) or at latest at the beginning of phase (4) because further treatment does not lead to any improvements but only increased energy consumption. In the actual experiments this point is related to the stabilized $\mathrm{pH}$ at about 1 , after which the major current carrier will be $\mathrm{H}^{+}$ions. Similar phases are thus found during electrodialtyic treatment of soil fines and sewage sludge ash. The focus in this investigation is recovery of $\mathrm{P}$ and simultaneous removal of heavy metals and it is important to finish the treatment to hinder significant loss of P into the catolyte.

311 The four phases are easiest distinguished for $\mathrm{Cu}$ and $\mathrm{Zn}$ in SSA-B (figure 4). Phase (1) is approximately 3125 days; Phase (2) between 5 and 7 days; Phase (3) is between 7 and 10 days, though not seen as a 313 decreased removal rate compared to the previous phase, but only from the stop in heavy metal removal 
314 of the already mobilized part, Phase (4) is after 10 days, where the distribution of $\mathrm{Cu}$ and $\mathrm{Zn}$ does not 315 change over time. The phases have different durations for $\mathrm{Cu}$ and $\mathrm{Zn}$ in SSA-A (figure 3). Phase (1) was 316 less than 3 days the change from phase (2) to (3) is around 5 days, as hereafter the concentration in the 317 solution of the suspension decreases. This means that the removal rate in the applied electric field is 318 faster than the rate with which heavy metal release from the ash occur. Phase (4) starts at about day 10. 319 In relation to $\mathrm{Pb}$ both were within phase (3), even with the longest durations. The optimal duration at the 320 conditions of the present investigation is about 7 days for Ash-A and 10 days for Ash-B. Distinguishing 321 the separation process into these phases can be useful when optimizing EDS as the experimental conditions can be optimized for each phase.

\subsection{The treated ash}

The concentrations of $\mathrm{Cu}, \mathrm{Pb}$ and $\mathrm{Zn}$ in the ash decreased over time in Ash A while they increased in ash

B during EDS (table 2). This distinct difference shows that whereas the heavy metals are found in 327 relatively high concentrations in the soluble ash particles of Ash A (under conditions of EDS) they are found in the least soluble particles in Ash B. This underlines the different characteristics of the two SSAs even though they are both from mono-incineration of sewage sludge in fluidized bed at $850^{\circ} \mathrm{C}$. The final concentrations of $\mathrm{Cu}$ and $\mathrm{Zn}$ were 3-4 times higher in Ash B after 14 days of EDS even though the initial concentration was lower. This might influence the possible uses of the ashes in construction materials, where high heavy metal concentrations can hamper the use.

\subsection{Purity of the filtrate with $P$}

The salt produced from evaporation of the water from the filtrate in experiment A6 (where the extraction of $\mathrm{P}$ and separation of heavy metals had reached slightly into phase 4 , i.e. the heavy metal cations are 
transported into the catolyte) is evaluated in relation to the heavy metal concentrations by comparison to

338 the limiting values for use of waste on agricultural land in Denmark (Miljøstyrelsen 2010). There are two sets of concentrations; the first is on a dry matter basis and the second are P related concentrations. The latter is only given for $\mathrm{Pb}$ and $\mathrm{Cd}$ of the four heavy metals of the investigation. The limiting values are shown in table 3. Soil contamination with Cd from phosphate fertilizer is a major issue. The Cd content in the salt was $0.9 \mathrm{mg} \mathrm{Cd} / \mathrm{kg}$, which is higher than the Danish limiting value of $0.8 \mathrm{mg} \mathrm{Cd} / \mathrm{kg}$ (table 3). The Cd contamination level in common P fertilizers ranges from trace to $300 \mathrm{mg} / \mathrm{kg}$ of dry product (Gupta et al 2014), and thus the Cd concentration in the salt is in the lower end of fertilizers. The P related concentration in the salt was $3.7 \mathrm{mg} \mathrm{Cd} / \mathrm{kg} \mathrm{P}$ which was less than the limiting value. An average Cd content in European fertilizers is $138 \mathrm{mg} / \mathrm{kg} \mathrm{P}$ (Davister 1996) and the salt contains significantly less. The total concentrations of $\mathrm{Cu}, \mathrm{Pb}$ and $\mathrm{Zn}$ in the salt were all below the limiting values. In addition, the $\mathrm{P}$ related limiting value for $\mathrm{Pb}$ was by far met in the salt.

The concentrations of macro elements (P, Ca, $\mathrm{Al}$ and $\mathrm{Fe}$ ) in the salt are shown in table 3. A SEM-EDX investigation of dry salt verified that the macro elements in the salt were only those given in the table 3. As aimed for, the salt had a very high content of $\mathrm{P}$ (24\% per weight) and calculated to $\mathrm{P}_{2} \mathrm{O}_{5}$ this corresponds to $56 \%$ per weight, which is higher than the economic grade of phosphate rock ranging from 25\% to 37\% (Gupta et al 2014). In case evaporation is chosen as method for further processing the filtrate towards use in fertilizer, it is of importance that the water soluble fraction of $\mathrm{P}$ in the salt was very high (92\%), which is very positive. Fe and $\mathrm{Al}$ phosphates are poorly soluble, and these could constitute a part of the salt, but as $66 \% \mathrm{Fe}$ and $60 \% \mathrm{Al}$ were in a water soluble form, less than half of these elements can be present as poorly soluble phosphates. In addition, the concentrations of $\mathrm{Fe}$ and $\mathrm{Al}$ were very low compared to that of $\mathrm{P}$. On a molar basis there were $9 \% \mathrm{Al}$ and $0.5 \% \mathrm{Fe}$ in relation to $\mathrm{P}$, so the maximum 
360 loss of water soluble phosphorous compounds due to precipitation of $\mathrm{Al}$ and Fe phosphates would be 361 less than $10 \%$. The molar ratio between $\mathrm{Ca}$ and $\mathrm{P}$ in the salt was 0.17 , but as both elements have high 362 water solubility poorly soluble calcium phosphates are not formed. Calcium dihydrogen phosphate is 363 soluble in weak acid and is the suggested form. The major part of the salt crystals is considered to be 364 phosphoric acid crystals, which are colorless and hygroscopic crystals, exactly as experienced for the 365 crystals formed in this project. The salt had good quality for use in fertilizer production i.e. high water 366 content of impurities in the filtrate, which allows for further processing towards fertilizer production.

\section{CONCLUSION}

SSA was used as secondary resource for P recovery in the present investigations. SSAs from two different municipal wastewater treatment plants were included. The SSAs contained slightly less P than phosphate rock used in commercial fertilizer production and more heavy metals. Simultaneous recovery of 374 phosphorous and separation of heavy metals from SSA was obtained in a two-compartment electrodialytic cell. The SSA was initially suspended in distilled water at the anode compartment and during application of an electric DC field, $\mathrm{pH}$ decreased in the suspension due to electrolysis at the anode. The acidification caused mobilization of $\mathrm{P}$ and heavy metals. In the applied electric field the heavy metals were transported over the cation exchange membrane into the catholyte. Higher extractions of P were obtained by EDS from both SSAs compared to chemical extraction at the same $\mathrm{pH}$. A longer duration of the EDS process to reach high P extraction was needed for one of the ashes, 10 days vs. 7 days, (as it had 
382 the anode compartment) with less than $20 \%$ of the original heavy metals for both ashes. A P-salt was 383 produced from the filtrate and the salt had a low content of impurities, which allows for further processing 384 towards fertilizer production.

\section{ACKNOWLEDGEMENTS}

387

388

389

390

391

392

393

394

395

396

397

398

399

400

401

402

403

Avedøre Spildevandscenter and Lynettefællesskabet supplied the experimental ashes. Funding from from Copenhagen Cleantech Cluster (CCC) as a GAP project.

\section{REFERENCES}

Aydin, I.; Aydin, F.; Saydut, A.; Bakirdere, E.G.; Hamamci, C. Hazardous metal geochemistry of sedimentary phosphate rock used for fertilizer (Mazıdag, SE Anatolia, Turkey). Microchemical Journal, $200991,63-69$

Cyr, M.; Coutand, M.; Clastres, P. Technological and environmental behaviour of sewage sludge ash (SSA) in cement-based materials. Cement Concrete Res, 2007, 37, 1278-1289

Davister, A. Studies and Research on Processes for the elimination of cadmium from phosphoric acid. OECD Proceedings - Fertilizers as a Source of Cadmium. IOMC. 1996 Paris. p. 21-30.

Donatello, S.; Cheeseman, C.R. Recycling and recovery routes for incinerated sewage sludge ash (ISSA): A review. Waste Management 2013, 33(11), 2328-2340

Donatello, S.; Freeman-Pask, A.; Tyrer, M.; Cheeseman, C.R. Effect of milling and acid washing on the pozzolanic activity of incinerator sewage sludge ash. Cement Concrete Comp, 2010a, 32, 54-61 
404 Donatello, S.; Tong, D.; Cheeseman, C.R. Production of technical grade phosphoric acid from incinerator 405 sewage sludge ash (ISSA). Waste Management, 2010b, 30, 1634-1642

Ebbers, B.; Ottosen, L.M.; Jensen, P.E. Comparison of two different Electrodialytic Cells for Separation 407 of Phosphorus and Heavy Metals from Sewage Sludge Ash, Chemosphere, 2015a, 125, 122-129

Ebbers, B., Ottosen, L.M., Jensen, P.E. Electrodialytic treatment of municipal wastewater and sludge for 409 the removal of heavy metals and recovery of phosphorus, Electrochimica Acta, 2015b. In Press.

Franz, M. Phosphate fertilizer from sewage sludge ash (SSA). Waste Management, 2008, 28, 1809-1818

Guedes, P.; Couto, N.; Ottosen, L.M.; Ribeiro, A.B. Phosphorus recovery from sewage sludge ash 412 through an electrodialytic process. Waste Management, 2014, 34, 886-892

Gupta, D.K.; Chatterjee, S.; Datta, S.; Veer, V.; Walther, C. Review. Role of phosphate fertilizers in heavy metal uptake and detoxification of toxic metals. Chemosphere, 2014, 108, 134-144

Jensen, P.E.; Ottosen, L.M.; Ferreira, C. Kinetics of Electrodialytic Extraction of Pb and Soil Cations 416 from Contaminated Soil Fines in Suspension, Journal of Hazardous Materials, 2006, 138(3), 493-499 Miljøministeriet, Miljøstyrelsen (Danish EPA) Anvendelse af affald til jordbrugsformål (In Danish). Vejledning No. 1, 2010

Nordstrom, D.K.; May, H.M. Aqueous equilibrium data for mononuclear aluminum species. In Environmental Chemistry of Aluminium. G. Sposito. CRC Press, Boca Raton, FL 1989, pp 29-53

Ottosen, L.M.; Jensen, P.E. Kirkelund, G.M. Electrodialytic separation of phosphorous and heavy metals 422 from two types of sewage sludge ash. Separation Science and Technology, 2014, 49, 1910-1920

Ottosen, L.M.; Kirkelund, G.M.; Jensen, P.E. Extracting phosphorous from incinerated sewage sludge 424 ash rich in iron or aluminum. Chemosphere 2013, 91(7), 963-969

Ottosen, L.M.; Pedersen, A.J.; Hansen, H.K.; Ribeiro, A.B. Screening the possibility for removing 426 Cadmium and other heavy metals from wastewater sludge and bio-ashes by an electrodialytic method 
427 Electrochimica Acta 2007, 52(10), 3420-3426

428 Pedersen A.J.; Ottosen, L.M.; Villumsen, A. Electrodialytic removal of heavy metals from different fly 429 ashes. Influence of heavy metal speciation in the ashes. Journal of Hazardous Materials 2003, B100, 65$430 \quad 78,2003$

431 Skoglund, N.; Grimm, A.; Ohman, M.; Bostrom, D. Effects on Ash Chemistry when Co-firing 432 Municipal Sewage Sludge and Wheat Straw in a Fluidized Bed: Influence on the Ash Chemistry by 433 Fuel Mixing, Energy \& Fuels, 2013, 27, 5725-5732

434 Takahashi, M.; Kato, S.; Shima, H.; Sarai, E.; Ichioka, T.; Hatyakawa, S.; Miyajri, H. Technology for 435 recovering phosphorous from incinerated wastewater treatment sludge. Chemosphere, 2001, 44, 23-39

436 Tirado, R., Allsop, M. Phosphorus in agriculture: problems and solutions. Greenpeace Research

437 Laboratories Technical Report (Review) 02-2012 (greenpeace.org).

438 Touaibia, D.; Kerdjoudj, H.; Cherif, A.T. Concentration and purification of wet industrial phosphoric 439 acid by electro-electrodialysis (Technical note). Journal of Applied Electrochemistry, 1996, 26, 1071$440 \quad 1073$

441 Viader, R.P., Jensen, P.E., Ottosen, L.M., Ahrenfeldt, J., Hauggaard-Nielsen, H. Electrodialytic 442 extraction of phosphorus from ash of low-temperature gasification of sewage sludge 443 2015, Electrochimica Acta, In Press.

444 Werther J., Ogada, T. Sewage sludge combustion. Prog Energ Combust Sci 1999, 25, 55-116 445 


\begin{tabular}{ccccc}
\hline & $\begin{array}{c}\text { Duration } \\
\text { (days) }\end{array}$ & $\begin{array}{c}\text { Dissolved ash } \\
(\%)\end{array}$ & $\begin{array}{c}\text { Final pH in } \\
\text { suspension }\end{array}$ & $\begin{array}{c}\text { Final concentrations in ash } \\
\mathrm{Cu} / \mathrm{Pb} / \mathrm{Zn} \\
(\mathrm{mg} / \mathrm{kg})\end{array}$ \\
\hline A1 & 3 & 27.2 & 2.1 & $540 / 180 / 1160$ \\
A2 & 5 & 44.5 & 1.7 & $390 / 220 / 1050$ \\
A3 & 7 & 50.8 & 1.6 & $250 / 170 / 1030$ \\
A4 & 10 & 54.3 & 1.1 & $210 / 160 / 840$ \\
A5 & 10 & 53.7 & 1.1 & $260 / 150 / 950$ \\
A6 & 10 & 53.9 & 1.1 & $260 / 140 / 1010$ \\
A7 & 14 & 53.9 & 1.0 & $600 / 120 / 930$ \\
\hline B1 & 5 & 26.2 & 4.3 & $510 / 140 / 2700$ \\
B2 & 7 & 42.8 & 2.1 & $690 / 140 / 4200$ \\
B3 & 10 & 64.7 & 1.2 & $700 / 140 / 4100$ \\
B4 & 14 & 65.5 & 1.0 & $690 / 130 / 4100$ \\
B5 & 16 & 63.7 & 1.1 &
\end{tabular}

447

448 Table 1: The duration and SSA varied between the experiments. Shown are also for the SSA the final pH, dissolution during 449 the experiment and concentrations of $\mathrm{Cu}, \mathrm{Pb}$ and $\mathrm{Zn}$. 


\begin{tabular}{lcc}
\hline & Ash A & Ash B \\
\hline $\mathrm{pH}\left(\mathrm{H}_{2} \mathrm{O}\right)$ & $9.6 \pm 0.1$ & $12.4 \pm 0.1$ \\
Conductivity $(\mathrm{mS} / \mathrm{cm})$ & $2.8 \pm 0.2$ & $10.3 \pm 0.1$ \\
Loss on ignition $\left(550^{\circ} \mathrm{C}\right)(\%)$ & $0.5 \pm 0.05$ & $3.0 \pm 0.12$ \\
Solubility in water $(\mathrm{g} / \mathrm{kg})$ & 15 & 66 \\
Water soluble Cl $(\mathrm{mg} / \mathrm{kg})$ & $25 \pm 1$ & $860 \pm 8$ \\
\hline $\mathrm{P}(\mathrm{g} / \mathrm{kg})$ & $110 \pm 1.1$ & $72.3 \pm 2.1$ \\
$\mathrm{Al}(\mathrm{g} / \mathrm{kg})$ & $21.6 \pm 0.3$ & $14.1 \pm 4.4$ \\
\hline $\mathrm{Zn}(\mathrm{mg} / \mathrm{kg})$ & $2030 \pm 14$ & $2180 \pm 65$ \\
$\mathrm{Cu}(\mathrm{mg} / \mathrm{kg})$ & $700 \pm 3.6$ & $480 \pm 12$ \\
$\mathrm{~Pb}(\mathrm{mg} / \mathrm{kg})$ & $115 \pm 2.3$ & $81 \pm 2.5$ \\
$\mathrm{Cd}(\mathrm{mg} / \mathrm{kg})$ & $3.2 \pm 0.1$ & $2.2 \pm 0.2$ \\
\hline
\end{tabular}

453

454

455

456

Table 2: Characteristics of the two investigated SSAs. 
457

\begin{tabular}{lcccccccc}
\hline & $\mathrm{P}$ & $\mathrm{Al}$ & $\mathrm{Ca}$ & $\mathrm{Fe}$ & $\mathrm{Cu}$ & $\mathrm{Pb}$ & $\mathrm{Zn}$ & $\mathrm{Cd}$ \\
\hline Total concentration (mg/kg) & 244,000 & 18,700 & 55,400 & 2,200 & 248 & 91 & 460 & 0.9 \\
P related concentration (mg/kg P) & & & & & 1,020 & 370 & 1,900 & 3.7 \\
Soluble in water (mg/kg) & 224,000 & \multirow{2}{*}{11,300} & 53,500 & 1,460 & 240 & 22 & 430 & 0.5 \\
Water solubility (\%) & 92 & 60 & 97 & 66 & 97 & 24 & 94 & 56 \\
\hline Limiting value (mg/kg) & & & & & 1,000 & 120 & 4,000 & 0.8 \\
Limiting value (mg/kg P) & & & & - & 10,000 & - & 100 \\
\hline
\end{tabular}

458

459 Table 3: Total concentrations, phosphorous related concentrations, water soluble concentrations and water solubility of

460 different chemical elements in the salt produced from experiment A6. The limiting values are from (Miljøstyrelsen 2010).

461

462

463 


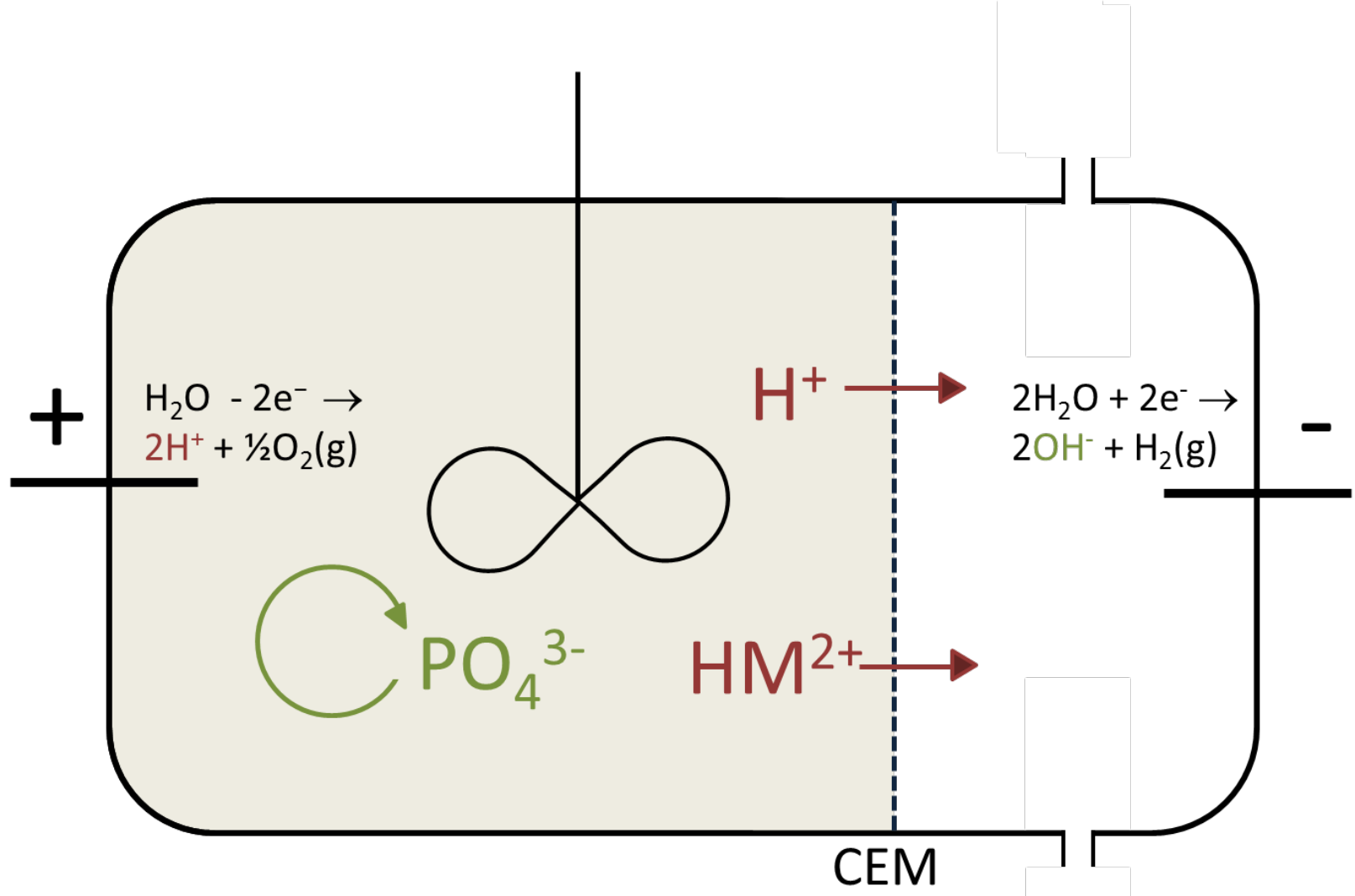

Figure 1: Two-compartment electrodialytic cell for simultaneous $P$ recovery and heavy metal separation from sewage sludge ash. The compartments are separated by a cation exchange membrane (CEM). The ash is suspended in water in the anode compartment. During the application of current, the suspension is acidified from electrolysis at the anode (reaction shown in the figure). In the acidic environment the $P$ and heavy metals are brought into solution and the heavy metal cations $\left(\mathrm{HM}^{2+}\right)$ are transported into the catholyte by electromigration. 
472

473

474

475

476

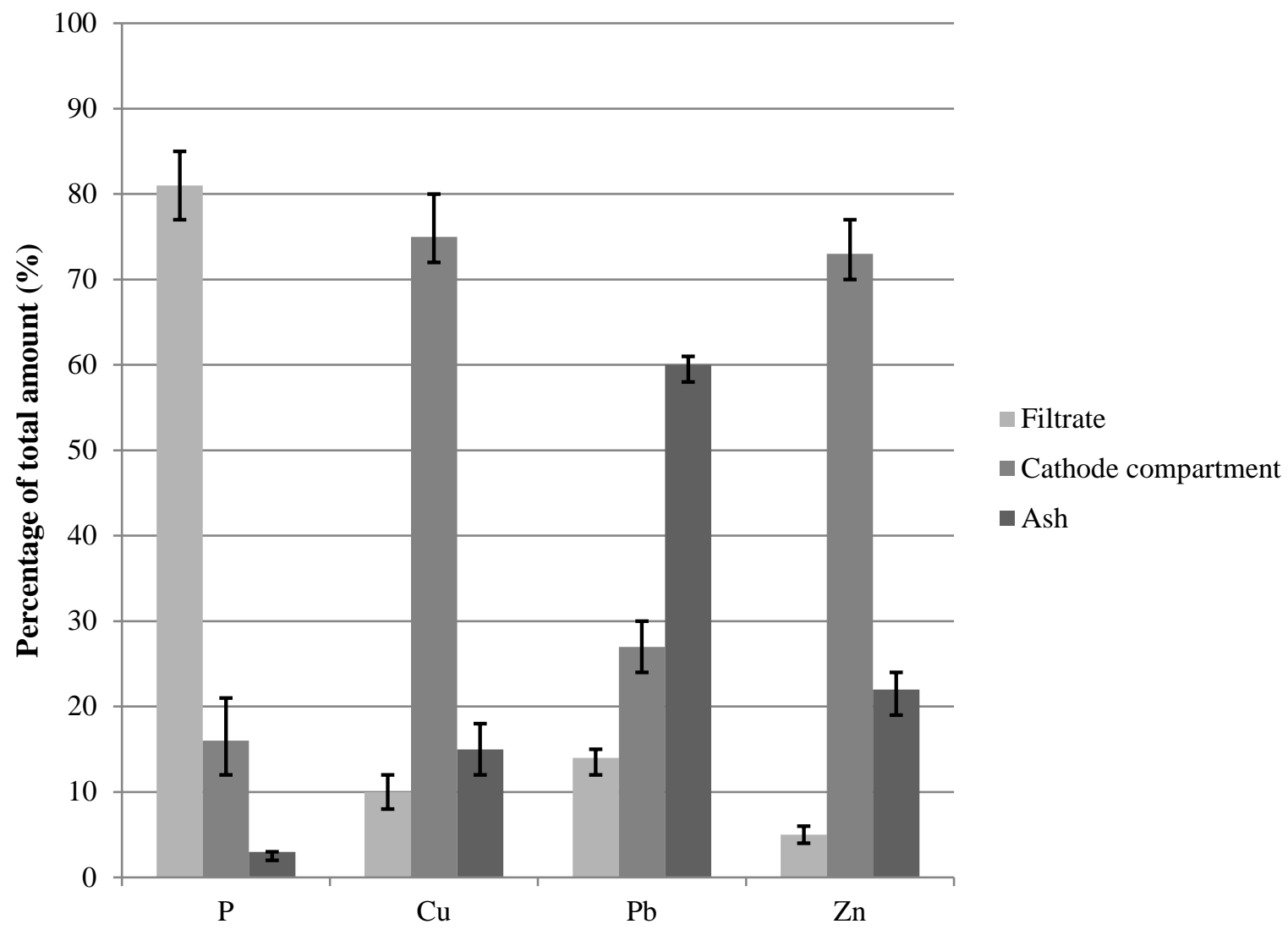

Figure 2: Repeatability of phosphorous and heavy metal distribution at the end of three similar experiments (A4A6). Mean values are shown in solid bars and the error bars shows minimum and maximum values. 

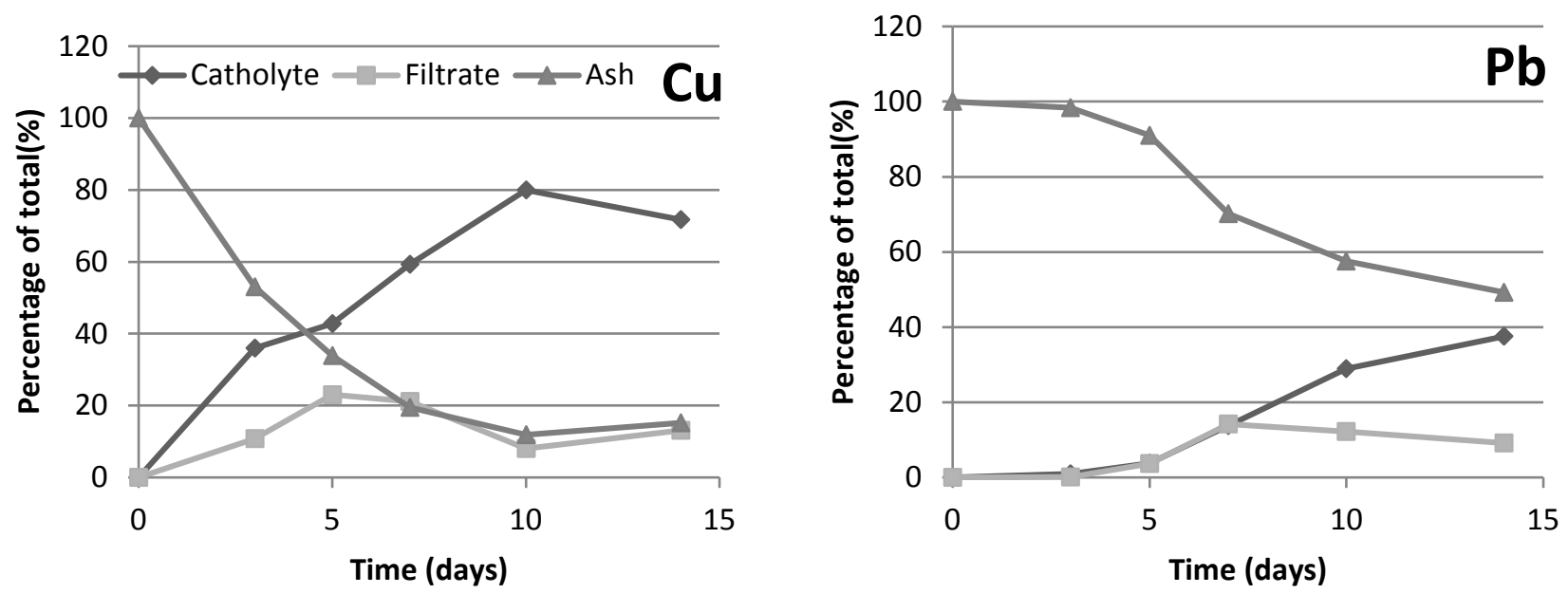

477
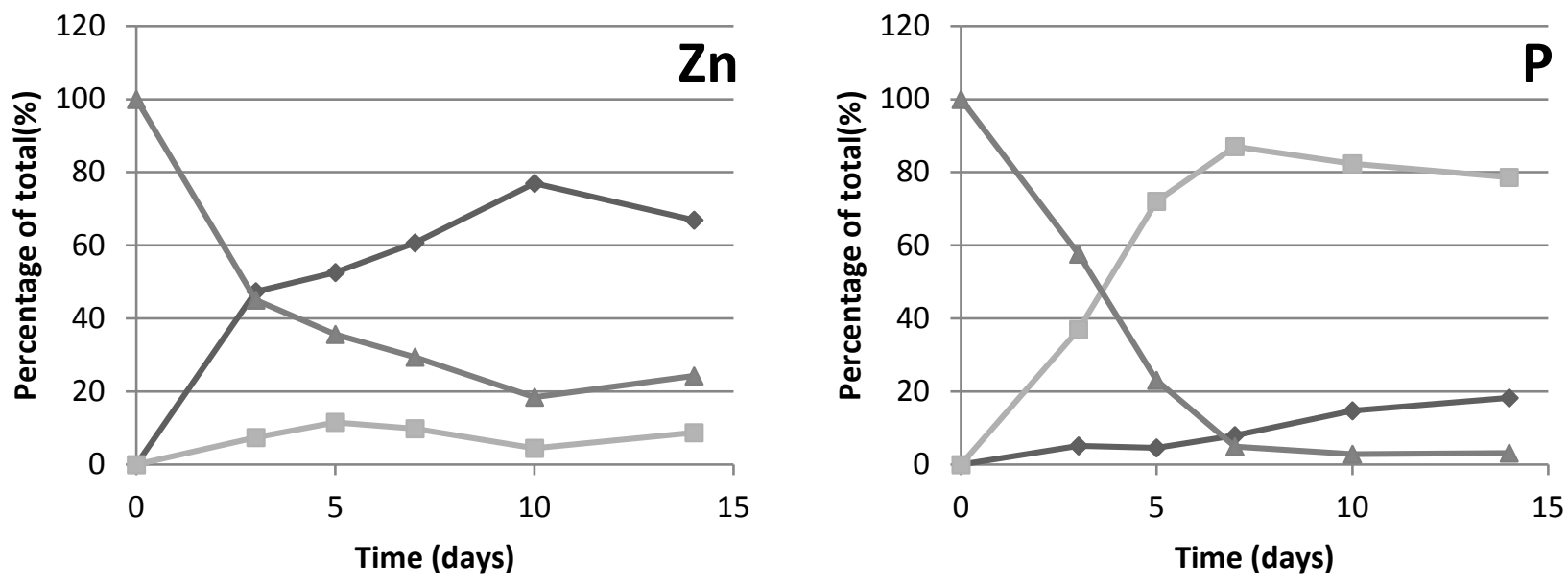

Figure 3: Distribution of $\mathrm{Cu}, \mathrm{Pb}, \mathrm{Zn}$ and $\mathrm{P}$ in the two-compartment cell over time for Ash-A 

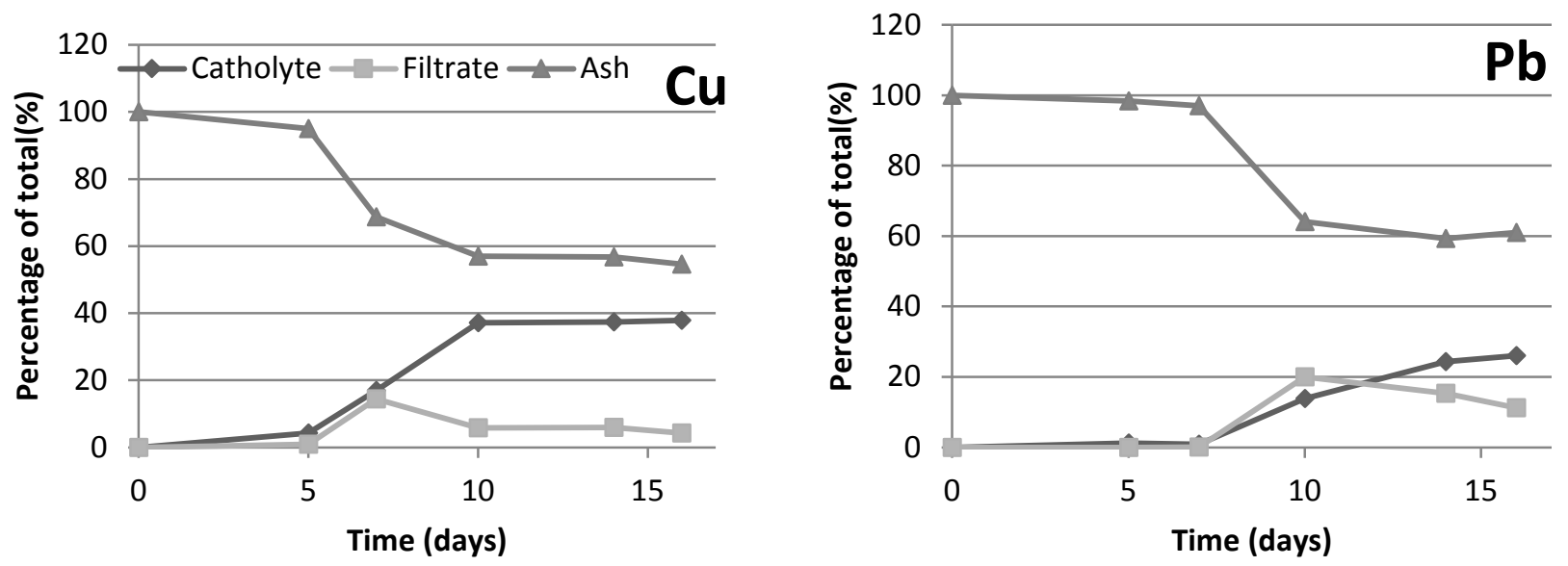

482
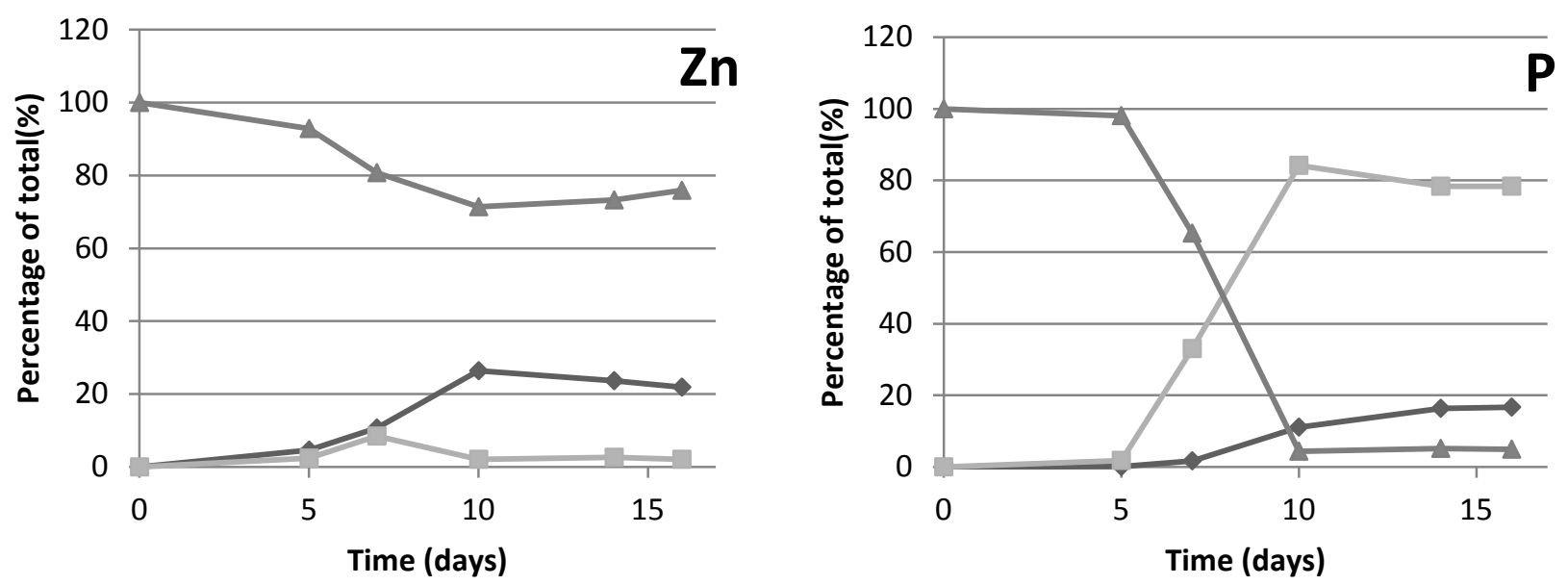

483

484

485

486

487

488

489

490

Figure 4: Distribution of $\mathrm{Cu}, \mathrm{Pb}, \mathrm{Zn}$ and $\mathrm{P}$ in the two-compartment cell over time for Ash-B 